\title{
Uji Toksisitas Ekstrak Daun Pandan Wangi (Pandanus amaryllifolius Roxb.) Dengan Metode Brine Shrimp Lethality Test (BSLT)
}

\author{
Dede Sukandar*, S. Hermanto, Emi Lestari \\ Program Studi Kimia Fakultas Sains dan Teknologi \\ UIN Syarif Hidayatullah Jakarta, \\ Jalan Ir. H. Juanda No 95 Ciputat 15412 Indonesia \\ email: ds_tea2007@yahoo.com
}

\begin{abstract}
Abstrak
Telah dilakukan penelitian untuk mengetahui toksisitas dari ekstrak daun pandan wangi menggunakan metode Brine Shrimp Lethality Test (BSLT). Ekstrak dibuat dengan cara maserasi menggunakan tiga macam pelarut, yaitu butanol, etil asetat, dan petroleum eter. Uji toksisitas dilakukan dengan menggunakan larva udang Artemia salina Leach yang berumur 48 jam. Efek toksik masing-masing ekstrak diidentifikasi dengan presentase kematian larva udang menggunakan analisis probit $\left(\mathrm{LC}_{50}\right)$. Ekstrak aktif kemudian diuji kandungan fitokimianya dan senyawa bioaktif yang terkandung di dalamnya dengan menggunakan GC-MS. Hasilnya menunjukkan ekstrak etil asetat bersifat toksik $\left(\mathrm{LC}_{50}: 288,4 \mathrm{ppm}\right)$. Senyawa yang terkandung dalam ekstrak etil asetat adalah senyawa terpenoid dan steroid.
\end{abstract}

Kata kunci : Ekstrak Daun Pandan Wangi, BSLT, Artemia salina Leach, LC $_{50}$, Fitokimia, GCMS

\begin{abstract}
An investigation to find out the toxicity of tray screw pine leaf extract has been done by using Brine Shrimp Lethality Test ( BSLT) method. Fragrant screw pine leaf extract was made by macerating with three kinds of solvent, i.e. butanol, ethyl acetate, and ether petroleum. Toxicity was conducted for prawn larva Artemia salina Leach of 48 hours age. Effect of toxicity from each extract identified with presentage of death of prawn larva and counted by probit analysis ( $\mathrm{LC}_{50}$ ). An active extract then characterized by phytochemistry content and bioactive compound by GC-MS analysis. The result showed that ethyl acetate extract was more toxic than another extract ( $\left.\mathrm{LC}_{50}: 288,4 \mathrm{ppm}\right)$. Futhermore, the bioactive compound of tray screw pine leaf was probably to be either terpenoid and steroid compound.
\end{abstract}

Keywords : Fragrant Screw Pine Leaf Extract, BSLT, Artemia salina Leach, Phytochemistry, GC-MS, LC $_{50}$

\section{PENDAHULUAN}

Bahan-bahan hayati telah digunakan oleh manusia untuk memenuhi berbagai keperluan hidup. Indonesia yang beriklim tropis memiliki sumber daya alam hayati yang sangat beranekaragam. Tumbuh-tumbuhan hutan tropik Indonesia memiliki peranan dalam era teknologi yang tidak kalah penting dengan sumber daya alam lainnya seperti gas, batu bara, mineral, dan lain-lain.

Dari segi kimia, sumber daya alam hayati ini merupakan sumber senyawa kimia yang tak terbatas jenis maupun jumlahnya.
Dengan demikian keanekaragaman hayati dapat diartikan sebagai keanekaragaman kimiawi yang mampu menghasilkan bahanbahan kimia, baik untuk kebutuhan manusia maupun organisme lain seperti untuk obatobatan, insektisida, kosmetika, dan sebagai bahan dasar sintesa senyawa organik yang lebih bermanfaat (Achmad, 1985).

Pengobatan secara tradisional sebagian besar menggunakan ramuan yang berasal dari tumbuh-tumbuhan baik berupa akar, kulit batang, kayu, daun, bunga, atau bijinya. Agar pengobatan secara tradisional dapat dipertanggungjawabkan maka 
diperlukan penelitian ilmiah seperti penelitian

di bidang farmakologi, toksikologi, identifikasi, dan isolasi zat kimia aktif yang terdapat dalam tumbuhan.

Salah satu tumbuhan yang banyak digunakan sebagai obat tradisional adalah pandan wangi, dengan nama ilmiah Pandanus amaryllifolius Roxb, termasuk genus pandanus dari suku Pandanaceae. Daun pandan wangi sering digunakan sebagai bahan penyedap, pewangi, dan pemberi warna hijau pada masakan. Selain itu juga berkhasiat untuk menghitamkan rambut, menghilangkan ketombe, rambut rontok, lemah saraf, tidak nafsu makan, rematik, sakit disertai gelisah, serta pegal linu (Dalimartha, 2002).

Daun pandan wangi mengandung alkaloid, saponin, flavonoida, tanin, polifenol, dan zat warna (Sugati dan Jhonny, 1991). Komposisi utama yang menyebabkan aroma pada pandan wangi tidak diketahui dengan pasti. Kemungkinan senyawa utama penyusun aroma pada daun pandan wangi adalah 2acetyl-1-pyrroline (2AP)(Buttery, 1983)

Sebuah penelitian (Sukandar, 2007) melaporkan tumbuhan pandan wangi memiliki beberapa senyawa kimia yang menjadi komponen penyusun minyak atsiri daun pandan wangi ( $P$. amaryllifolius Roxb.) yaitu : 3-alil 6-metoksi fenol, 3-metil $2(5 \mathrm{H})$ furanon, dietil ester 1,2-benzenadikarboksilat, dan 1,2,3-propanetril ester asam dodekanoat.

Uji pendahuluan senyawa aktif pada ekstrak tanaman biasanya dilakukan dengan hewan uji. Salah satu hewan uji yang sesuai adalah brine shrimp (udang laut) A. salina Leach, sejenis udang-udangan primitif dan pertama kali ditemukan di Lymington, Inggris pada tahun 1755 dan termasuk famili crustaceae tingkat rendah dari phylum arthropoda (Purwakusuma, 2007).

Brine Shrimp Lethality Test (BSLT) pertama kali diperkenalkan oleh Michael, dkk pada tahun 1956. Metode pengujian ini didasarkan pada bahan senyawa aktif dari tumbuhan yang bersifat toksik dan mampu membunuh larva $A$. salina Leach. dan dapat digunakan sebagai uji praskrining aktivitas antikanker (Meyer et al, 1982).

Penelitian ini dilakukan untuk mengetahui toksisitas pandan wangi terhadap larva udang A. salina Leach melalui uji BSLT sebagai uji pendahuluan untuk mengetahui senyawa bioaktif dari pandan wangi.

\section{METODE PENELITIAN}

\section{Bahan dan Alat}

Sampel daun pandan wangi ( $P$. amaryllifolius Roxb.) dikumpulkan dari Kelurahan Beji Timur, Kecamatan Beji, Depok. Identitas biologi ditentukan di Botani Herbarium Bogoriense, Cibinong dan spesimennya disimpan di herbarium tersebut. Larva A. salina Leach berasal dari Laboratorium Kimia LIPI, Serpong.

Bahan untuk ekstraksi terdiri dari nbutanol, etil asetat dan petroleum eter, sedangkan untuk uji toksisitas menggunakan DMSO (Dimetilsulfoksida).

Identifikasi ekstrak aktif dilakukan dengan GC-MS 6890 N-5973 Agilent dengan kolom ( HP-5, $0.25 \mathrm{~mm} * 30 \mathrm{~m} * 0.25 \mu \mathrm{m}$ ).

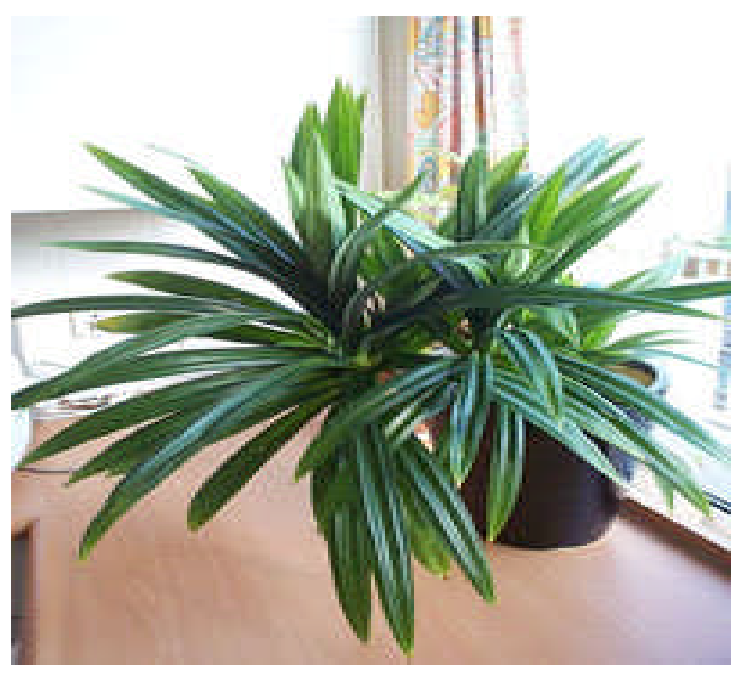

Gambar 1. Tumbuhan Pandan Wangi

\section{Ekstraksi}

Sebanyak $25 \mathrm{~g}$ daun pandan wangi yang telah dikeringkan dan dihaluskan, dimaserasi dengan butanol, etil asetat, dan petroleum eter (3 x 24 jam). Setelah dilakukan penyaringan masing-masing ekstrak dipekatkan pada suhu $40-65{ }^{0} \mathrm{C}$ hingga diperoleh padatan gum berwarna hijau (ektrak butanol 2,43 g, etil asetat $1,71 \mathrm{~g}$, dan petroleum eter $0,66 \mathrm{~g}$. Ketiga ekstrak kemudian diuji toksisitasnya dengan metode BSLT.

\section{Uji Toksisitas}

Sebanyak 4 mg ekstrak sampel dilarutkan dalam $10 \mu \mathrm{L}$ Dimetil Sulfoksida 
(DMSO) $10 \mathrm{ppm}$ dan ditambah pelarut air laut sampai $2 \mathrm{ml}$ (2000 ppm) sebagai larutan A. Larutan A $8 \mathrm{~mL}$ dipipet dan ditambahkan pelarut sampai $10 \mathrm{~mL}(1600 \mathrm{ppm})$ sebagai larutan B. Larutan B $5 \mathrm{~mL}$ dipipet dan ditambahkan pelarut sampai $10 \mathrm{~mL}$ (800 ppm) sebagai larutan C. $5 \mathrm{~mL}$ larutan $\mathrm{C}$ dipipet dan ditambahkan pelarut sampai $10 \mathrm{~mL}$ (400 ppm) sebagai larutan D. $5 \mathrm{~mL}$ larutan $\mathrm{E}$ dipipet dan ditambahkan pelarut sampai $10 \mathrm{~mL}$ (200 ppm) sebagai larutan E. Selanjutnya, dari larutan A, $\mathrm{B}, \mathrm{C}, \mathrm{D}, \mathrm{E}$ masing-masing dipipet sebanyak $100 \mu \mathrm{L}$ lalu dimasukkan ke dalam microplate yang sudah ditera $200 \mu \mathrm{L}$. Setiap konsentrasi dibuat tiga kali pengulangan.

Ke dalam microplate berisi ekstrak dimasukkan 10 ekor larva A. Salina Leach yang berumur 48 jam. Sebagai kontrol, digunakan 10 ekor larva $A$. Salina Leach di dalam $200 \mu \mathrm{L}$ air laut tanpa diberi ekstrak. Campuran dibiarkan selama 24 jam di bawah cahaya lampu neon 18 watt. Setelah 24 jam, larva udang yang mati dari masing-masing wadah dihitung. Nilai $\mathrm{LC}_{50 \mathrm{x}}$ ditentukan menggunakan analisis probit. Ekstrak yang memiliki toksisitas tertinggi kemudian diuji kandungan fitokimianya.

\section{Skrining Fitokimia}

Skrining fitokimia bertujuan mengetahui kandungan alkaloid, flavonoid, steroid, terpenoid, dan saponin dalam ekstrak etil asetat daun pandan wangi, yang mempunyai efek biologi menghambat pertumbuhan kanker, mikroba, sebagai antioksidan, menurunkan kolesterol darah, dan kadar glukosa darah, bersifat antibiotik, serta menimbulkan efek peningkatan kekebalan (Sumastuti, 2002). Identifikasi Flavonoid dilakukan dengan cara menambahkan serbuk $\mathrm{Mg}$ dan $2 \mathrm{ml} \mathrm{HCl} 2 \mathrm{~N}$ pada $2 \mathrm{~mL}$ larutan ektrak. Senyawa flavonoid akan menunjukkan warna jingga sampai merah. Identifikasi Alkaloid dilakukan dengan cara $3 \mathrm{ml}$ larutan ekstrak ditambahkan dengan $1 \mathrm{ml} \mathrm{HCl} 2 \mathrm{~N}$ dan $6 \mathrm{ml}$ air suling, kemudian dipanaskan selama 2 menit, didinginkan dan disaring. Filtrat diperiksa dengan pereaksi Dragendorff terbentuk endapan jingga, Wagner terbentuk endapan coklat, dan Mayer terbentuk endapan putih. Identifikasi Steroid dan Terpenoid dilakukan dengan pereaksi Lieberman-Burchard. Warna biru atau hijau menunjukkan steroid sedangkan warna merah menunjukkan terpenoid. Identifikasi Saponin dilakukan dengan penambahan metanol lalu dipanaskan selama beberapa menit. Kemudian dikocok vertikal selama 10 detik. Hasil uji positif jika timbul busa stabil selama beberapa menit (Harborne, 1987).

\section{Identifikasi GC-MS.}

Ekstrak etil asetat yang memiliki toksisitas tertinggi diidentifikasi kandungan senyawanya menggunakan GC-MS dengan kondisi suhu oven $\left(50^{\circ} \mathrm{C}-290^{\circ} \mathrm{C}\right)$, Interface $\left(290{ }^{\circ} \mathrm{C}\right)$, kontrol mode (split), tekanan $(20.8$ psi), total flow $(23.7 \mathrm{ml} / \mathrm{min})$, split ratio : (200 : 1), split flow (199 $\mathrm{ml} / \mathrm{min})$, gas $(\mathrm{He})$, dan detector (MSD).

\section{HASIL DAN PEMBAHASAN}

Uji toksisitas dengan Brine Shrimp Lethality Test (BSLT) merupakan praskrining terhadap senyawa aktif yang terkandung dalam

Tabel 1. Hasil Uji Toksisitas Ekstrak Daun Pandan Wangi dengan Metode Brine Shrimp Lethality Test (BSLT)

\begin{tabular}{|c|c|c|c|c|}
\hline Ekstrak & Konsentrasi $(\mathrm{ppm})$ & Mortalitas $(\%)$ & LC $_{50}(\mathrm{ppm})$ & Keterangan \\
\hline \multirow{4}{*}{ Butanol } & 800 & 25,71 & \multirow{2}{*}{ Tidak toksik } \\
& 400 & 8,47 & & \\
& 200 & 3,49 & & Toksik \\
Etil asetat & 100 & 0 & 288,4 & \\
& 400 & 64,81 & & Tidak toksik \\
& 200 & 36 & & \\
Petroleum & 100 & 1,61 & & \\
eter & 800 & 6,25 & $912.010,84$ & \\
& 200 & 3,29 & & - \\
\hline Kontrol & 100 & 0 & 0,00 & \\
\hline
\end{tabular}


ekstrak tanaman. Suatu ekstrak dianggap toksik apabila memiliki nilai $\mathrm{LC}_{50}<1000$ ppm sedangkan untuk senyawa murni dikatakan toksik apabila $\mathrm{LC}_{50}$ nya $<200$ ppm (Meyer, dkk. 1982). Hasil uiji toksisitas ekstrak butanol, etil asetat, dan petroleum eter daun pandan wangi dengan metode Brine Shrimp Lethality Test (BSLT) tertera pada Tabel 1.

Diantara ketiga ekstrak yang diuji, ekstrak etil asetat mempunyai $\mathrm{LC}_{50}$ sebesar 288,4 ppm atau kurang dari 1000 ppm. Hal ini menunjukkan ekstrak etil asetat bersifat toksik terhadap udang A. salina Leach.
Hasil kontrol dengan air laut (mortalitas $0 \%$ ), menunjukkan bahwa larva yang mati disebabkan senyawa toksik pada ekstrak, bukan karena faktor lainnya.

Hasil skrining fitokimia menunjukkan adanya senyawa steroid (+), sedangkan senyawa terpenoid, alkaloid, flavonoid, dan saponin tidak terdapat (-) dalam ekstrak etil asetat.

Analisa dengan GCMS menunjukkan hasil sebagaimana terlihat pada Gambar 2.

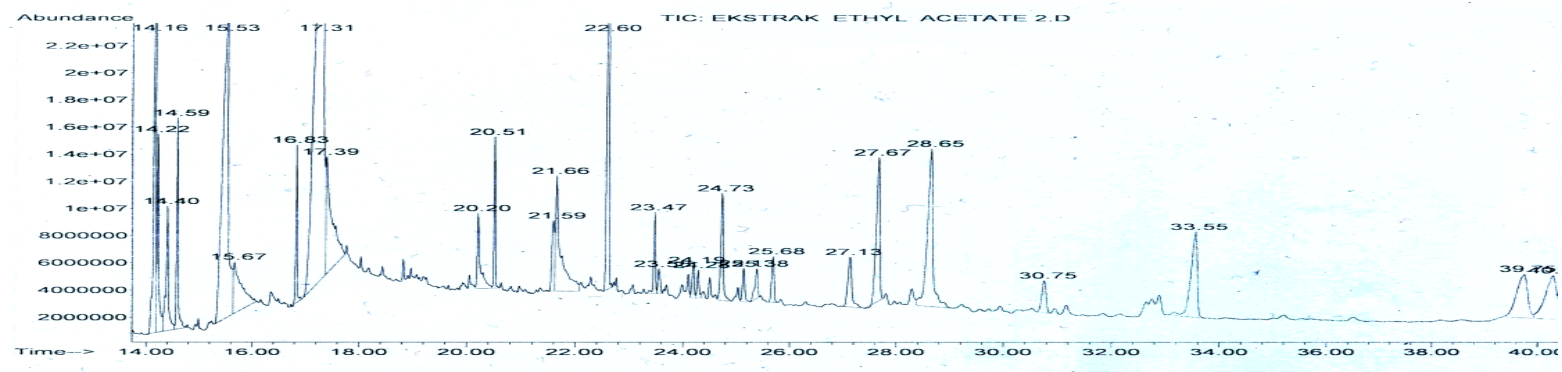

Gambar 2. Hasil analisa GCMS ekstrak etil easetat daun pandan wangi

Tabel 2. Senyawa yang terkandung dalam ekstrak etil asetat daun Pandan Wangi

\begin{tabular}{|c|c|c|c|c|}
\hline Puncak & Waktu retensi $(\mathrm{Rt})$ & Luas puncak & $\begin{array}{c}\text { Kemiripan } \\
(\%)\end{array}$ & Kemungkinan nama senyawa \\
\hline 1 & 14,16 & 6,77 & 94 & Neofitadiena \\
\hline 2 & 14,22 & 2,42 & 83 & $3,7,11,15$ - tetrametil-2 - heksadekena \\
\hline 3 dan 4 & 14,40 dan 14,59 & 2,09 dan 2,25 & 93 & Neofitadiena \\
\hline 5 & 15,53 & 12,78 & 98 & Asam Palmitat \\
\hline 6 & 15,67 & 2,41 & 90 & Fitol \\
\hline $7 \mathrm{dn} 8$ & 16,83 dan 17,31 & 1,33 dan 25,65 & 90 dan 91 & Metil Linolenat \\
\hline 9 dan 10 & 17,39 dan 17,52 & $3,08 \mathrm{dn} 0,46$ & 70 dan 95 & Asam 9,12-oktadekadienoat \\
\hline 11 & 17,56 & 1,03 & 96 & Asam Palmitat. (-monogliserida \\
\hline 12 & 20,20 & 0,82 & 68 & Di-(2-etilheksil) pthalat \\
\hline 13 & 20,51 & 1,28 & 91 & Etil Linolenat \\
\hline 14 & 21,60 & 0,98 & 93 & Skualena \\
\hline 15 & 21,66 & 1,43 & 91 & Solanesol \\
\hline 16 & 22,61 & 6,40 & 95 & 4ロ, 50-kolestan 4,5-epoksi \\
\hline 17 & 23,47 & 0,94 & 94 & $\begin{array}{l}\text { Alpha. -(p-klorobenzoil)-p-kloro } \\
\text { asetofenon }\end{array}$ \\
\hline 18 & 23,55 & 0,37 & 70 & Gama. -cis-seskuisiklogeraniol \\
\hline 19 & 24,19 & 0,53 & 94 & Gama.-tokoferol \\
\hline 20 & 24,28 & 0,42 & 76 & 3,5-dedihidro stigmastan -6,22-dien \\
\hline 21 & 24,73 & 1,81 & 98 & Stigmastan-3,5-dien \\
\hline 22 dan 26 & 25,14 dan 27,67 & 0,52 dan 3,62 & 25 dan 95 & Vitamin E \\
\hline 23 & 25,38 & 0,59 & 89 & Kampesterol \\
\hline 24 & 25,68 & 0,76 & 96 & Stigmastan-5,22-dien-3-ol, \\
\hline 25 . & 27,13 & 1,36 & 96 & Gama. -sitosterol \\
\hline 27. & 28,65 & 6,06 & 96 & Neofitadiena \\
\hline 28. & 30,75 & 0,89 & 97 & Asam Linolenat \\
\hline 29. & 33,55 & 3,35 & 94 & 1-metil-2,3-dihidro-10- \\
\hline 30. & 39,75 & 3,46 & 55 & Fenilimidazo[1,2-g]1,6] naphthiridin- \\
\hline 31. & 40,29 & 4,16 & 83 & $5(1 \mathrm{H})$-on \\
\hline
\end{tabular}


Berdasarkan data di atas terdapat 4 golongan senyawa utama yang terkandung dalam ekstrak etil asetat, yaitu asam lemak (lemak), terpenoid, steroid, dan vitamin. Diantara senyawa-senyawa tersebut yang diduga bersifat toksik terhadap udang A. salina Leach adalah senyawa terpenoid dan steroid. Hal ini didasarkan pada laporan Indriyani, dkk.
2006, yang menyatakan bahwa ekstrak daun pecut kuda bersifat toksik terhadap larva $A$. salina Leach dan senyawa yang terkandung di dalamnya adalah senyawa terpenoid. Selain itu, senyawa terpenoid dikenal pula sebagai salah satu golongan senyawa kimia dalam tanaman yang memiliki aktivitas antikanker dan antioksidan (Lisdawati, 2002).

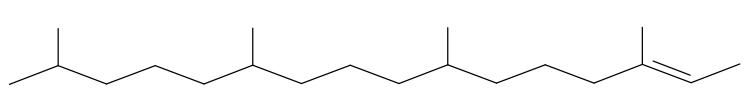

$3,7,11,15$-tetram etil 2 -heksadekena

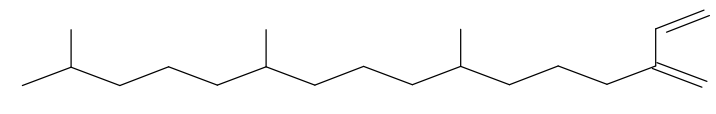

ne ofitadien a<smiles>CC(=CCO)CCCC(C)CCCC(C)CCCC(C)C</smiles>

fitol

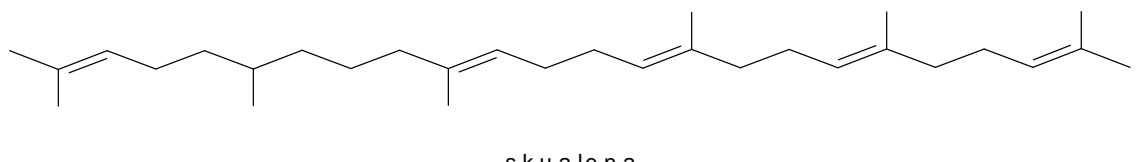

skualena

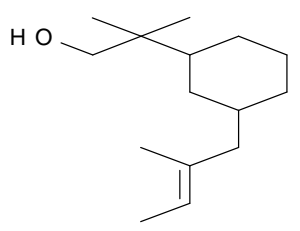

gam a-cis-siklogeraniol

Gambar 3. Beberapa Senyawa Terpenoid dalam Ekstrak Etil Asetat Daun Pandan Wangi

Senyawa terpenoid yang terdapat dalam ekstrak etil asetat meliputi neofitadiena, 3,7,11,15- tetrametil 2-heksadekena, fitol, skualena, dan gamma.-cis-seskuisiklogeraniol (Gambar 3). Pada skrining fitokimia, senyawa terpenoid tidak teridentifikasi, tetapi pada hasil analisa GC-MS menunjukkan adanya senyawa terpenoid. Hal ini terjadi disebabkan beberapa kemungkinan antara lain penggunan pelarut yang sudah kadaluarsa atau konsentrasi terpenoid yang sangat kecil sehingga tidak dapat teridentifikasi.

Berdasarkan analisa GC-MS, salah satu senyawa terpenoid yang diduga bersifat toksik terhadap udang A. salina Leach. yang memiliki waktu retensi 22,61, kualitas $98 \%$ dan luas puncak $6,40 \%$ adalah skualena. Senyawa ini bermasa molekul relatif $(\mathrm{m} / \mathrm{z}) 409\left(\mathrm{M}^{+1}=410\right)$ dengan rumus molekul $\mathrm{C}_{30} \mathrm{H}_{49}$. Spektrogram MS senyawa skualena tertera pada Gambar 4.

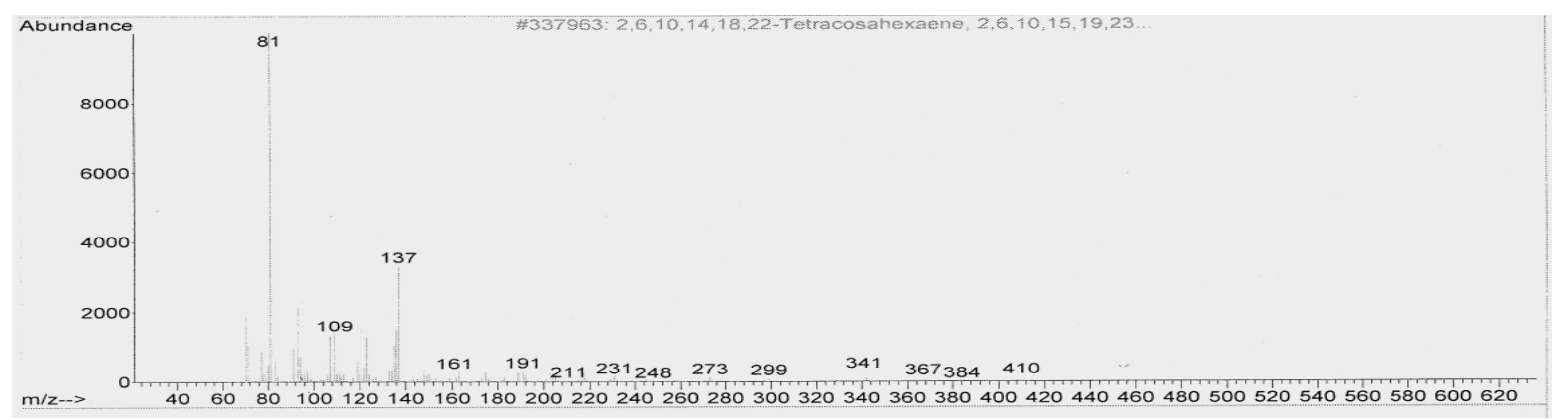

Gambar 4. Spektrogram MS Senyawa Skualena 

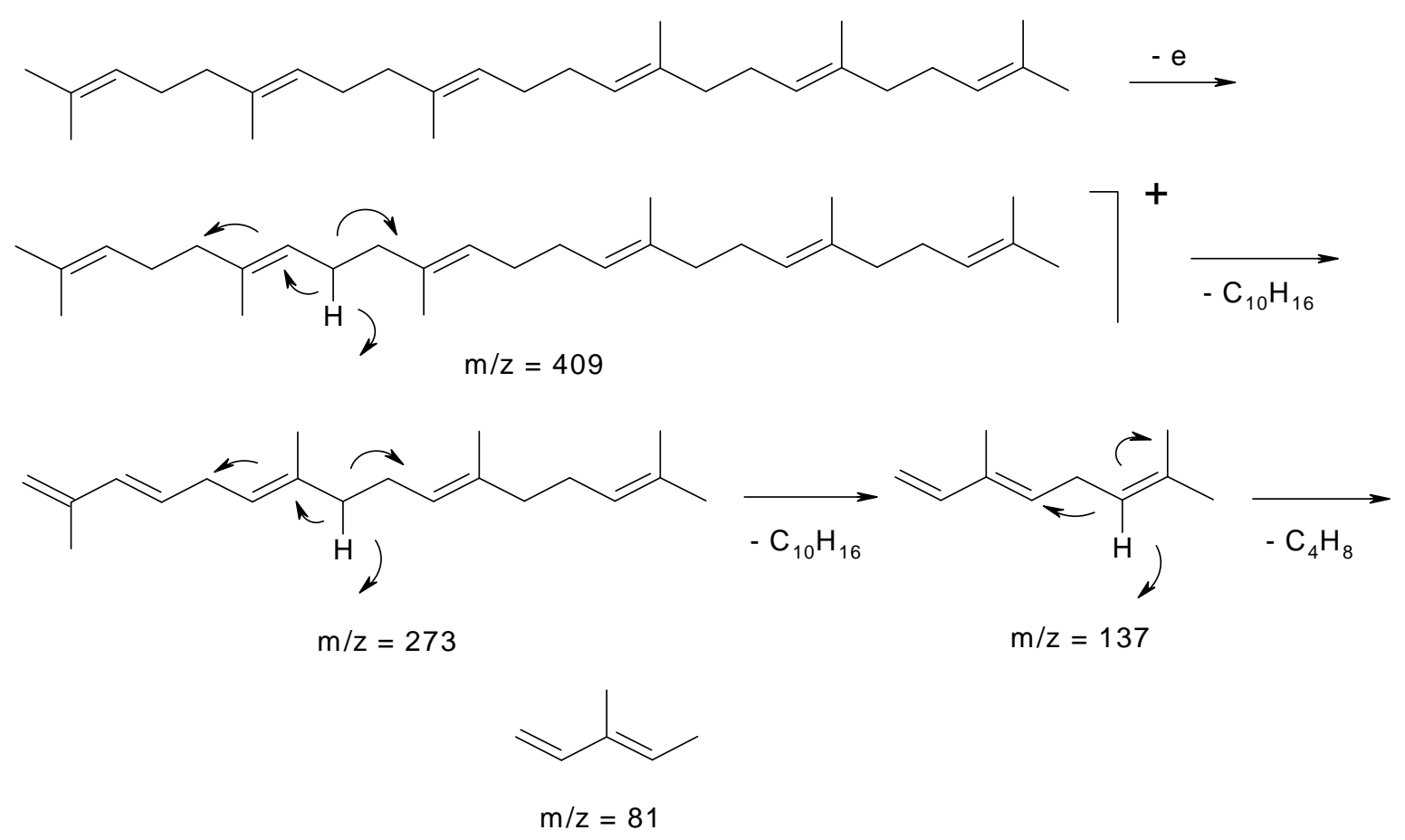

Gambar 5. Pola Fragmentasi Skualena yang Disarankan

Selanjutnya berdasarkan hasil penelitian Sukardiman (2004), senyawa steroid pada ekstrak metanol Marchantia planiloba Steph. mampu membunuh larva $A$. salina Leach dengan $\mathrm{LC}_{50} 247,10 \pm 5,28 \mu \mathrm{g} / \mathrm{ml}$. Fitosterol yang juga dikenal sebagai sterol tumbuhan seperti stigmasterol, kampesterol, sitosterol, ergotamin (provitamin $\quad$ D) memiliki kemampuan untuk berkompetisi dengan kolesterol dalam penyerapannya di dalam usus. Kompetisi ini mengakibatkan berkurangnya jumlah kolesterol yang dapat diserap oleh tubuh (Ostlund, dkk. 2003). Selain itu, sterol juga dapat berperan dalam mencegah terjadinya kanker (De Stefani, dkk. 2000).

Senyawa steroid yang terdapat dalam ekstrak etil asetat antara lain solanesol, $4 \alpha, 5 \alpha-$ kolestan 4,5-epoksi, 3,5-dedihidro stigmastan 6,22-dien, , stigmastan-3,5-dien, kampesterol, stigmastan- 5,22-dien-3-ol, dan gamma.sitosterol (Gambar 6).

Hasil analisa GC-MS juga menunjukkan adanya salah satu senyawa steroid yang bersifat toksik terhadap udang A. salina Leach. yang berada pada waktu retensi 28,65 , luas puncak 6,06 \%, dan kualitas $96 \%$ adalah senyawa gamma-sitosterol. Senyawa ini memiliki massa molekul realif $(\mathrm{m} / \mathrm{z}) 414\left(\mathrm{M}^{+}\right.$ $=414$ )sesuai dengan rumus molekul $\mathrm{C}_{29} \mathrm{H}_{50} \mathrm{O}$.
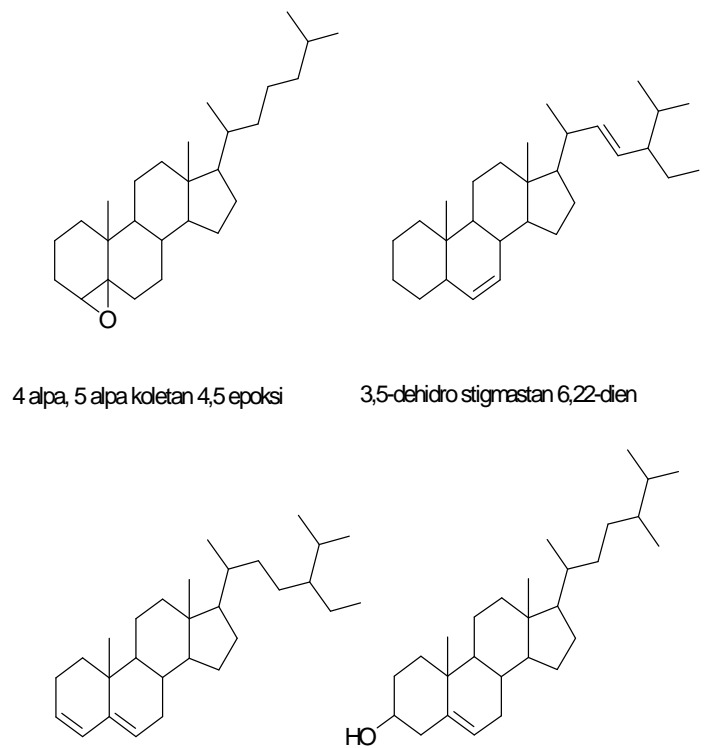

3,5-dehidro stigmastan 6,22-dien

stigmastan 3,5-dien<smiles>CC(C)C(C)CCC(C)C1CCC2C3CC=C4CC(O)CCC4(C)C3CCC12C</smiles>

kaempesterol (ergostan 5-en-3-d)

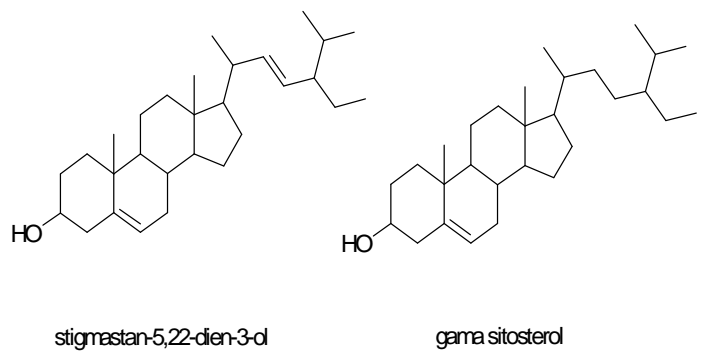

Gambar 6. Beberapa Senyawa Steroid dalam Ekstrak Etil Asetat Daun Pandan Wangi 
Spektrogram MS senyawa gamma-sitosterol tertera pada Gambar 8 berikut ini.

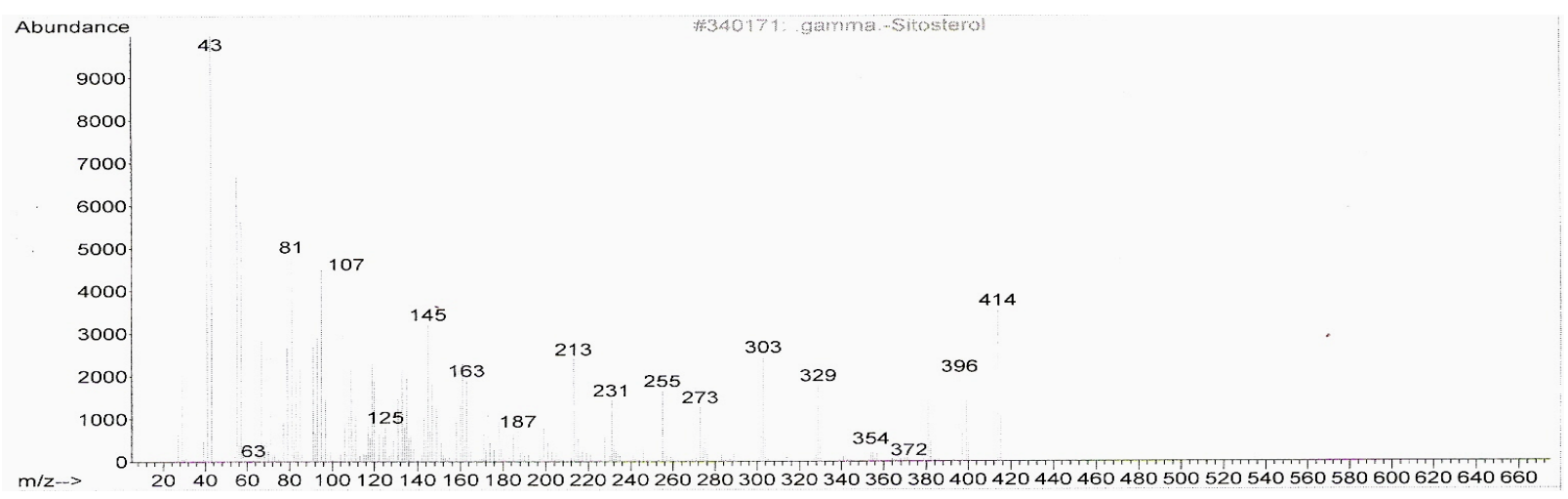

Gambar 7. Spektrogram MS Senyawa gamma-sitosterol

Pola fragmentasi gamma-sitosterol yang terlihat pada gambar 8 di bawah ini. disarankan sesuai dengan hasil analisa MS

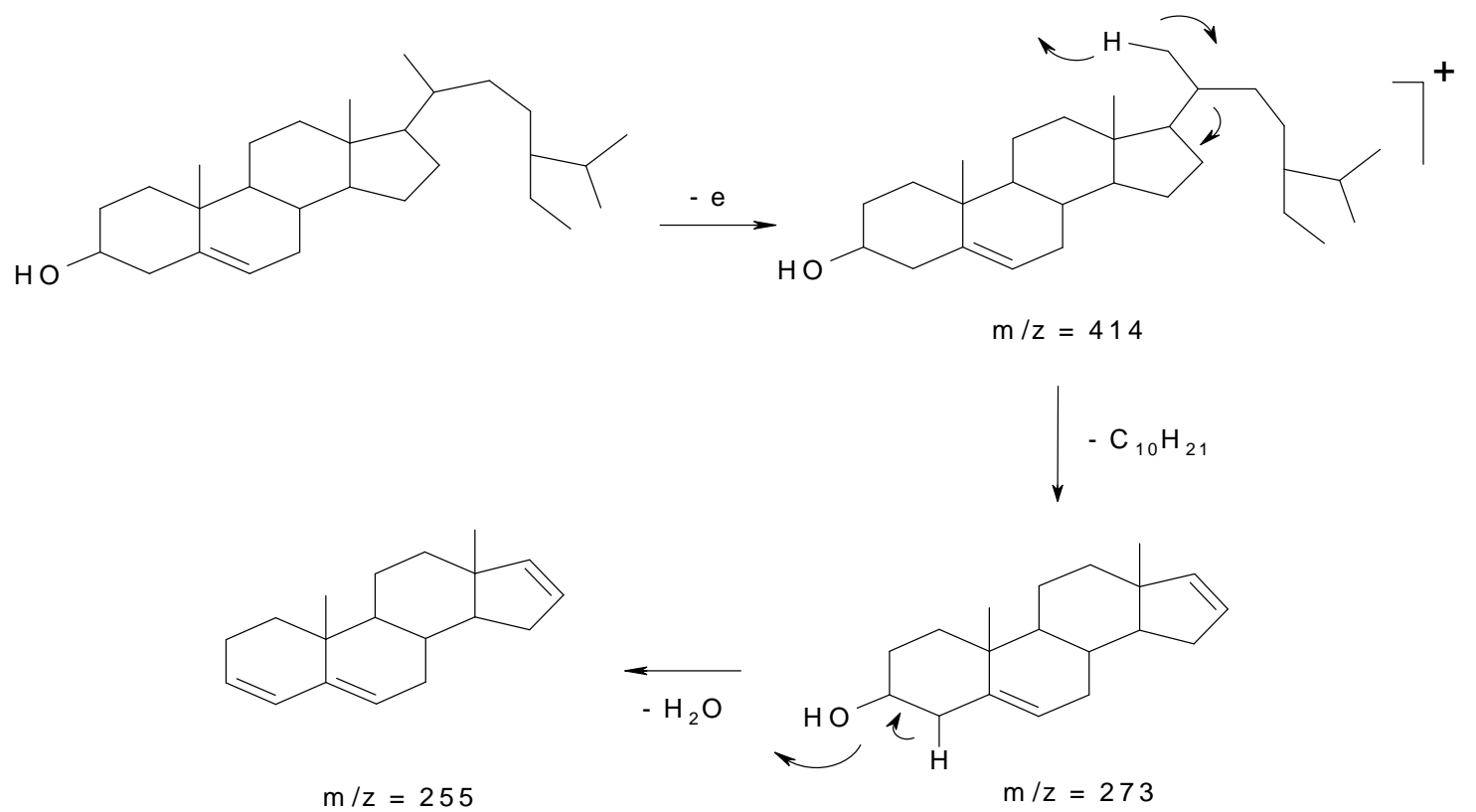

Gambar 8. Pola Fragmentasi gamma-sitosterol yang Disarankan

\section{KESIMPULAN}

Kesimpulan yang dapat diambil dari penelitian ini yaitu :

1. Ekstrak etil asetat daun pandan wangi bersifat toksik terhadap larva udang $A$. salina Leach. dengan nilai $\mathrm{LC}_{50}$ sebesar 288,4 ppm.

2. Golongan senyawa yang terdapat pada ekstrak etil asetat adalah senyawa terpenoid dan steroid.

\section{UCAPAN TERIMA KASIH}

Terima kasih kami ucapkan kepada pimpinan dan staf Herbarium Bogoriense Bidang Botani Pusat Penelitian Biologi-LIPI Cibinong Jawa Barat, yang telah membantu mengidentifikasi spesimen tumbuhan. Terima kasih pula kami sampaikan kepada Kepala Laboratorium Kimia-LIPI Serpong, yang telah membantu pengujian tokisitas dengan Brine Shrimp Lethality Test (BSLT). 


\section{DAFTAR PUSTAKA}

1. Achmad. S.A., (1986), Kimia Organik Bahan Alam. Universitas Terbuka, Jakarta.

2. Buttery, R. G., Ling, L. C., Juliano, B. O. and Turnbaugh, J. C., (1983), Cooked rice aroma and 2-acetyl-1-pyrroline. J.Agric. Food Chem., 31, 823-826.

3. Dalimartha, Setiawan, (2007), Obat Tradisional, Pandan wangi (Pandanus amaryllifolius Roxb.). http://www.pdpersi.co.id. 13 April 2007.

4. De Stefani, Eduardo, et al., (2000), Plant Sterols and Risk of Stomach Cancer: A Case-Control Study in Uruguay. Nutrition and Cancer 37 (2): 140-144.

5. Harborne, J. B., (1987), .Metode Fitokimia Penuntun Cara Modern Menganalisis Tumbuhan, Terbitan Kedua. ITB, Bandung.

6. Indrayani, Lany. Hartati Soetjipto dan Lydia Sihasale, Skrining Fitokimia dan Uji Toksisitas Ekstrak Daun Pecut Kuda (Stachytarpheta jamaicensis L. Vahl) Terhadap Larva Udang Artemia salina Leach. Berk. Penel. Hayati: 12, (2006), 57-61.

7. Lisdawati, Vivi, (2007), Buah Mahkota Dewa (Phaleria macrocarpa). Toksisitas, Efek Antioksidan dan Efek Antikanker Berdasarkan Uji Penapisan Farmakologi. http://mahkotadewa.com/VFC/vivi.htm. 17 September, 2007.

8. Meyer, B. N., Ferrigni, N. R., Putnam, J.E., Jacobson, L. B., Nichols, D. E., and McLaughlin, J. L., (1982), Brine shrimp: a convenient general bioassay for active plant constituents. Planta Medica, 45:31-34.

9. Ostlund RE, Racette, SB, and Stenson WF., (2003), Inhibition of cholesterol absorption by phytosterol-replete wheat germ compared with phytosterol-depleted wheat germ. Am J Clin Nutr 77 (6): 13851589.

10. Purwakusuma, Wahyu, (2007), Artemia salina (Brine Shrimp). http://www.ofish.com/PakanIkan/artemia.php. $\quad 30$ Oktober 2007.

11. Sugati, S. dan Johnny, R.H., (1991), Inventaris Tanaman Obat Indonesia.
Badan Penelitian \& Pengembangan Departemen Kesehatan RI, Jakarta.

12. Sukandar, Dede, (2007), Isolasi dan Penentukan senyawa kimia minyak atsiri tumbuhan pandan wangi ( $P$. amaryllifolius Roxb. ). Prosiding Seminar BKS MIPA, UIN Syarif Hidayatullah, Jakarta, $42: 53$.

13. Sukardiman, Abdul Rahman, Nadia Fatma Pratiwi, (2004), Uji Praskrining Aktivitas Antikanker Ekstrak Eter dan Ekstrak Metanol Marchantia cf. planiloba Steph. Dengan Metode Uji Kematian Larva Udang dan Profil Densitometri Ekstrak Aktif. Majalah Farmasi Airlangga, Vol.4 No.3

14. Sumastuti, R., Sonlimar, M., (2002), Efek Sitotoksik Ekstrak Buah dan Daun Mahkota Dewa [Phaleria macrocarpa (Scheff) Boerl.] Terhadap Sel Hela. Farmakologi Fakultas Kedokteran UGM, Yogyakarta.

15. Thomas TG, Rao S, Lal S., (2004), Mosquito larvicidal properties of essential oil of an indigenous plant, Ipomoea cairica Linn. Jpn J Infect Dis 57: 176-177.

16. WHO (2005), Guidelines for laboratory and field testing of mosquito larvicides. World Health Organization Communicable Disease Control, Prevention and Eradication WHO Pesticide Evaluation Scheme.

17. Yang YC, Lee SG, Lee HK, Kim MK, Lee SH, Lee HS., (2002), A piperidine amide extracted from Piper longum $L$. fruit shows activity against Aedes aegypti mosquito larvae. J Agric Food Chem. 50(13): 3765-3767.

18. Zulkifli N., (2005), Proses pembuatan minyak jarak sebagai bahan bakar alternatif. Laporan penelitian tim Departemen Teknologi Pertanian USU Medan. 